vro, especialmente a administradores práticos. Só o layout (arranjo ou disposição física) está faltando na apreciação. Um milagre 0 que 0 autor conseguiu colocar em 236 páginas. E, se ao ler a resenha, alguém acredita ter visto parênteses demais - e isso é uma desvantagem do texto original - deve o leitor ficar ciente de que a tradução é ótima e o tradutor merece aplausos por ter evitado galicismos, que costumam subrepticiamente entrar nas traduções de livros franceses. $E$ vamos esperar 0 segundo volume de um ótimo manual.

\section{O negro na civilização brasileira}

Por Arthur Ramos. Rio de Janeiro, Livraria Editora da Casa do Estudante do Brasil, 1971. 252 p. v. 1 (Coleção Arthur Ramos). Reed.

$\mathrm{Na}$ década de 20 exaltava-se a nacionalidade brasileira em reação à ameaça de descaracterização pela onda imigrantista; buscava-se a autenticidade na cultura brasileira. Era a passagem do Brasil rural ao Brasil urbano que se refletia no plano das idéias (o Brasil "autêntico", rural, contraposto ao Brasil "nãoautêntico", urbano, imigrantista). Em decorrência, valorizavase o folclore quase como uma ideologia. Nesse momento, surge 0 interesse estratégico pelo negro enquanto "homem do povo", como expressão de brasilidade, de cultura popular.

Começava a ganhar vulto a antropologia cultural no Brasil, e o conceito de cultura passou a fornecer à intelectualidade brasileira elementos "democráticos", manipuláveis, condicionados historicamente. No que tange ao plano teórico de abordagem do negro brasileiro, a fase era de reação à influência ger- manófila de fins do século passado, tão marcante que transpareceu mesmo através dos estudos rigorosos de Nina Rodrigues. Significava libertação de um quadro de referências meramente biológico e negativo, nãomanipulável, atenuado somente pela miscigenação, contraditoriamente considerada indesejável por constituir entrave ao desenvolvimento nacional - 0 subdesenvolvimento do Pais era até então atribuído à fragilidade racial que resultou do mestiçamento com o negro. Se o "mal" passava a ser localizado na cultura, seria contornável e possivel a redenção do povo brasileiro.

A figura principal dessa época, sem dúvida alguma, é o médico, antropólogo e etnólogo Arthur Ramos. Tendo sido, a principio, muito influenciado pelas interpretações psicanalíticas do problema, formuladas pelo mestre Nina Rodrigues, a partir de certo momento passa a conduzir seus trabalhos nos moldes culturalistas.

A obra de que ora nos ocupamos, $\mathbf{D}$ negro na civilizaçăo brasileira, escrita originalmente em ingles, destinou-se especialmente aos cientistas norte-americanos, na época extremamente carentes de informaçōes precisas sobre a complexa situação do negro na vida brasileira. Por isso os propósitos do livro são introdutórios, gerais. Outras obras do autor completam a análise; esta é esquemática.

Nos primeiros capítulos, Arthur Ramos trata dos aspectos propriamente históricos da escravidão no Brasil, compreendidos entre a introdução do tráfico negreiro e a Abolição, para depois estender-se na abordagem da participação do negro em vários setores importantes da vida nacional. 
Do principio ao fim nota-se a preocupaçăo e o esforço do autor em evidenciar que não se constituiu, no Brasil, um sistema de castas em torno de linhas raciais, pois os negros e mulatos participaram, sem restriçōes, dos processos de desenvolvímento cultural do Pais. Provavelmente ai esteja um dos fatores que esclarecem a posiçäo de Arthur Ramos diante do movímento abolicionista e da integração do negro na sociledade inclusiva. Dissemos "um dos fatores", porque, se nos reportarmos à parca bibliografia existente na epoca, relacionada pelo próprio autor no final do livro, notaremos que ele esmerou-se ao máximo, empregando o arcabouço teórico e emplrico acessivel na ocasiāo. Só na década de 50 a sociologia despertaria para os problemas empíricos da realidade nacional, deixando de ser apenas ensalstica, e, consequientemente, a abordagem do negro brasileiro póde contar com um instrumental de que a antropologia achavase alheia. Ao invés de "adorno", de expressão cultural, o negro vem a ser focalizado como "problema social", como expressão de estrutura, dal a preocupaçăo com problemas como mobilidade, competiçāo, integraçăo, constituição de ideologia etc. No dizer de L.A. Costa Pinto, enquanto os negros morriam pelos morros, os antropólogos permaneciam preocupados com os "produtos culturais" do elemento negro: suas tradições, festas, cultos etc.

Escudados nas novas concepçốes, podemos volver a fase culturalista e reconhecer nela as tinturas da ideologia da democracia racial no Brasil. E o próprio Arthur Ramos, seu lídimo representante, que corrobora essa assertiva, não podendo ser mais explicito quando afirma: "Os ne- gros libertos derramaram-se por todo o território nacional. Passaram a ser homens como os outros, distribuindo e cobrando - seu trabalho, de acordo com suas aptidões. Nas fazendas, empregaram-se no trabalho assalariado. E nas cidades, eles se misturavam, na vida social e na famllia, trazendo o seu concurso vigoroso à obra de formação da sociedade brasileira" (p. 87-8). Ao mesmo tempo, admite que não ocorreu uma catástrofe depois da Abolição, porque a cafeicultura tornara-se a atividade econômica básica do País e já estava admitindo mão-de-obra estrangeira. Seria procedente, entăo, a suposição de que os estrangeiros e os exescravos começaram a trabalhar em igual. dade de condiçōes, como assalariados típicos, em uma sociedade que se dizia "aberta"? As pesquisas emplricas realizadas pelos sociólogos demonstraram que, em grande medida, isto não se deu, especialmente nos estados do sul do País, incluindo São Paulo. Diante disso, percebe-se que, na fase culturalista, nảo se tem uma visão realista do negro.

$\mathrm{Na}$ análise do movimento abolicionista, também é dessa perspectiva que 0 autor parte. Vejase, por exemplo, a ênfase que confere à pressão da opiniāo pública, em que se representa. vam "todas as camadas sociais" (p. 83), não considerando os suportes reais das posiçōes pró ou anti-abolicionistas, nem distinguindo os interesses economicos diversos que se achavam envolvidos no processo político 'da abolição da escravidão negra. Nâo surpreende, portanto, que de tal angulo o negro seja visto como "o principal artífice da sua própría emancipação" (p. 89), quando recorria a fugas, a violência e aos movimentos organizados para alforria. Ora, estas foram formas de reação que seriam pouco eficazes, não estando presentes as condições abaladas no final do perlodo escravista. Os movimentos orga. nizados restringiam-se principalmente ao meio urbano, onde foi possível a acumulação de alguns recursos pelos "negros de ganho" ou "negros de aluguel". As confrarias e irmandades de negros, que o autor tanto valoriza, não tiveram a iniciativa dos escravos, pois decorriam de polltica deliberada da Igreja Católica, que zelava por nẫo misturar "nações" diferentes na mesma associação, mantendo umas afastadas das outras e concorrendo entre si. Igualmente as festas dos reizados e dos cor. gos, citadas nesta obra, ao invés de organizadas para a defesa - encaminhamento pacífico da libertaçäo, como pretende Arthur Ramos, atuavam como estabilizadoras inócuas das tensōes reivindicativas e eram até estimuladas pelo poder público, pois limitavam-se a uma espécie de "contestação ritual" do verdadeiro poder vigente.

A esta altura cabe considerar que o autor arma uma cilada para si, cometendo um deslize, pois anteriormente, em $\mathbf{A}$ aculturação negra no Brasil (Cla. Editora Nacional, 1942), no capítulo intitulado 0 negro e a república, havia colocado o problema em ter- 139 mos bem mais realistas, afirmando que a Abolição aconteceu por uma imposição de ordem econômica - os fazendeiros paulistas "libertaram-se dos escravos" - e que, depois dela, os ex-escravos foram jogados a própria sorte, para concorrerem como assalariados com os imigrantes, plenamente amparados pelo Governo. Disse ele textual. mente: "E começou a última etapa de um calvário que năo 
teve os seus líricos e os seus poetas para cantar, como os altiloqüentes da aboliçăo" ( $p$. 173) e mais adiante: "A República desconheceu o negro" (p. 174).

Quando 0 autor afirma: "Durante toda a campanha abolicionista, foram os negros os mais ardentes defensores da causa" (p. 94), está-se referindo a Luiz Gama, André Rebouças, José do Patrocinio, Joaquim Nabuco etc. Estes, como outros negros livres, conseguiram impor-se na sociedade "branca" auxiliados pelo paternalismo de "brancos". São exceçōes que năo alteram fundamentalmente a ordem; antes são válvulas de escape para - sistema, que revelam aceitação individualista e ultra-seletiva de certos negros pela sociedade inclusiva. E o que acontece no campo da música, da pintura, da escultura, da arquitetura, das letras e das ciências. Aqui, entäo, perguntamos: o que conta nas obras deles è o seu valor e o reconhecimento no "mundo branco"? Os artistas negros, pós-libertação, compõem uma "elite" desvinculada das massas de cor? Se os conteúdos e os estilos deles conformam-se nos da sociedade inclusiva, muitas vezes moldados "à européia", não podem ser considerados expoentes autênticos da "raça". Por exemplo: Gonçalves Dias destacou-se näo 140 como poeta da negritude, mas como indigenista; Castro Alves, também de ascendência negra, apresentava a mesma visão piedosa e paternalista dos brancos do estrato dominante, a quem interessava desvencilhar-se da mäo-de-obra escrava; Cruz e Souza, que gritava contra as pressöes do ambiente em virtude da pretensa inferioridade étnica, denotava anseios nitidamente assimilacionistas; $e$ assim por diante. Na época dos estudos de Arthur Ramos, jấ se diferenciava uma nascente "elite intelectual" negra, vinculada a movimentos reivindicatórios que se acompanhavam de uma ideologia de desmascaramento racial, mas ele nấo a captou.

Mais uma vez aflora a ideolo. gia da democracia racial, quando - autor pretende enumerar vultos negros que se projetaram na política brasileira republicana ou nas forças militares a não o consegue: "Entre nós, atualmente, O Negro näo se separa dos restantes dos componentes bran$\cos$ e mulatos, do Exército. $E_{\text {, }}$ por isso, não há estatísticas oficiais para o cômputo de soldados e marinheiros negros nacionais" (p. 185). "A inexistência de linha de cor e desigualdade política e social impedem que se destaquem os seus nomes, em biografias separadas de vultos negros na politica brasileira" (p. 189).

Quando muito, Arthur Ramos alcança distinguir a presença do preconceito de classe, ao afirmar que o problema do negro é - mesmo problema das classes pobres, em que se acha diluido e de cujas reivindicaçōes toma parte, onde a linha de cor é bastante atenuada, senão inexis. tente. Aceita que nos estados do Sul do Pais, embora a legislação não estabeleça separaçöes, "o preconceito de cor se estabelece na opinião pública" (p. 191), principalmente em virtude da presença de um contingente considerável de imigrantes bran$\cos$.

Nesse sentido, o autor fornece pistas para a compreensăo dos movimentos negros em São Paulo, por exemplo, seu caráter relvindicativo, integracionista e igualitário, mas não as explora até as últimas conseqüências. Uma análise dos Estatutos da Frente Negra Brasileira, que ele reproduz na integra, por exemplo, traz à tona uma tomada de consciência do estado de anomia social e a aspiraçäo de superá-10, o despertar para a luta contra a estereotipaçäo negativa, para a necessidade de manipulação de técnicas sociais que facilitem ou promovam a ação conjugada com vistas a ascensão social, a busca de ampliação do horizonte cultural do negro etc. Obviamente, em vista de nossas consideraçōes anteriores, nem mesmo a genialidade do autor conseguiria atingir este nivel de profundidade, naquela ocasiäo. Por isso reconhecemos e valorizamos o pioneirismo do autor e de sua obra. Reafirmamos também que os méritos de Arthur Ramos só podem ser apurados mediante a leitura de todos os seus estudos publicados e levando-se em conta as limitaçōes da abordagem culturalista.

Marineide do Lago Salvador dos Santos 